\title{
Digital Transformation in the Nigeria Construction Industry: The Professionals' View
}

\author{
Fidelis Okechukwu Ezeokoli ${ }^{1}$, Kevin Chuks Okolie ${ }^{1}$, Peter Uchenna Okoye ${ }^{1, *}$, \\ Christopher Chidi Belonwu ${ }^{2}$
}

\author{
${ }^{1}$ Department of Building, Nnamdi Azikiwe University, Nigeria \\ ${ }^{2}$ The Nigerian Institute of Building, National Secretariat, Nigeria
}

Copyright $\bigcirc 2016$ by authors, all rights reserved. Authors agree that this article remains permanently open access under the terms of the Creative Commons Attribution License 4.0 International License

\begin{abstract}
This study examined the perception of construction professionals and the extent of digital transformation in the Nigeria construction industry. A questionnaire survey was carried out where 84 copies of questionnaires containing information relating to digital technologies trends and transformation were randomly administered to the selected construction professionals in Anambra State Nigeria. 80 were completed, returned and found useful, thus, giving a response rate of $95.24 \%$. Data collected were analysed and presented using mean, percentages, charts and relative importance index (RII). The study revealed that $69 \%$ and $12 \%$ of the professionals viewed digital transformation as opportunity and threat respectively, whereas; $19 \%$ viewed it as both threat and opportunity. It further revealed that $63 \%$ were satisfied with their firms' readiness to transform digitally. The study then observed that application of digital technologies among construction firms in the study area was still at infancy due to lack capacity, critical knowledge and digital transformation enthusiasm among managerial teams. It was therefore, evident that digital transformation would help the industry to better its data storage and management capacity, increase employee productivity and gain competitive advantage. The study recommended collaboration between government and relevant regulatory bodies in Nigeria construction industry to workout appropriate roadmap that would position the industry in the right track towards transforming digitally.
\end{abstract}

Keywords Construction Professionals, Digital Technology, Digital Transformation, Drivers, Nigeria Construction Industry, Threats

\section{Introduction}

The quest to remain afloat and competitive in this digitalised world and advancement in Information \& Communication Technology have made digital transformation a hot debate topic for the moment and as a driving force for innovation and transformation for industries around the world [1-7]. Digitising is no longer an option for but a must do for an organisation to remain in business both present and in future $[1,8]$. In fact, the much-anticipated digital era is now reality [3,7,9], since the volume of businesses conducted electronically recently have increased tremendously due to the fact that most digital channels have become part and parcel of our everyday life [3,10,11]. The International Data Group (IDG) observed that the current focus of digital transformation initiatives are in the areas of IT, operation and websites/ecommerce with IT leading the way in terms of process improvement [12].

Digitisation simply means the conversion of analogue information into digital information which entails the intersection of new technologies, new capabilities, and changing customer behaviour [13], besides, going digital is not about technology; rather making customers' lives easier [13]. On the hand, digital transformation, according to [14], is the re-alignment of, or new investment in technology and business models to more effectively engage digital consumers at every touch point in the customer experience lifecycle. Furthermore, digital transformation means the innovation to connect technology, data science, devices, design, and business strategy to change a business process or customer [8]. The sole purpose of this transformation is to make business digital; through this, puts the customer, device, organisation or business process at the centre of change and improve agility, revenue and cost which help the business compete for digital customers $[8,15]$. It also helps organisations become more efficient and productive, remain competitive, achieve meaningful growth and sustainability $[1,16]$

Regrettably, the construction industry which is often one of the key sectors of any economic is grappling with lots of challenges. When compared to many other industries globally, the construction industry has been traditionally slow at technological development. It has not also undergone any major disruptive changes; and has not widely applied advances in processes such as "lean". As a result, efficiency gains have been meagre. To buttress this fact, in the United 
States of America for example, over the last 40 years, labour productivity in the construction industry has actually fallen [17]. Some of the problems have been inefficiency and lack of productivity, low profitability, low investment in research and development and training [18]. Moreover, too many of the industry's clients are dissatisfied with its overall performance which have been attributed to its fragmented nature of project delivery, labour intensive nature of the process and apparent difficulty of industry towards adopting new technologies [19-22].

Furthermore, Philip and Thompson [11] stressed that the future of construction industry is facing a high degree of complexity, extreme competition and uncertainty with respect to the outcomes of climate change, availability of resources and the disruptive nature of innovation. Changes in owners' demands and more complex facilities require new approaches in both design and construction [23]. These scenarios require innovative approach, unfortunately, construction industry globally is perceived to be non-innovative and there is much room for improvement. It has even been argued that the higher the levels of innovation in the construction industry the greater the likelihood that it will increase its contribution to economic growth [24]. It is widely accepted that promotion of innovation and innovative thinking is a pre-requisite to any competitive advantage [25]. To this end, Egan [21] proposed that service and product improvement and company profitability can only be achieved through innovation.

Therefore, digital transformation is more important now than before. We live in an era of transformation of technology in social values and the way work is done. In order to meet an increasing global and competitive environment, organisations are undergoing re-engineering, work process re-design, and other forms of restructuring. How the Nigeria construction industry is responding to this change is a subject of investigation. On this premise therefore, this study is aimed at examining the perception of construction professionals and the extent to which Nigeria construction industry is responding to digital transformation with a view to determining the drivers of and threats to digital transformation in the Nigeria construction industry.

\section{Literature Review}

\subsection{Construction Industry and Digital Transformation}

Construction industry according to [26] may be viewed as that sector of the economy which, through planning, design, construction, maintenance and repair, and operation, transforms various resources into constructed facilities. It is a sector of the economy that transforms various resources into constructed physical economic and social infrastructure necessary for socio-economic development [27,28]. The industry contributes significantly to the Gross Domestic Product (GDP) of any nation. In Nigeria for instance, the industry contributed about $4.13 \%$ to the total real GDP in the first quarter of 2016[29]. Also, around the world the industry has fared well, both in job creation and socio-economic development of any nation.

The industry just like every other sector is facing a paradigm shift as new technologies otherwise referred to as disruptive technology is gathering momentum in the world. The driving forces in the construction industry indicate that the ability to innovate is quickly becoming a competitive necessity [23]. Bossink [30] agreed that driving innovation on the trans-firm, intra-firm, and inter-firm level in the network of organisations is an opportunity for managers of both public and private organisations to develop, improve, and renew their organisations' positions in the market, the quality of their organisations' projects, and the cooperative structure of the industry as a whole. Stressing, Bahl [8] argued that no industry is immune to the impact of digital disruption, even the highly-regulated industries, such as financial services, are under intense pressure to recast their operations. Also, this wave of disruption is not just for companies; society is also feeling the heat of transformation towards a better future that is digitally driven [31]. Hence, technologies are changing businesses today and are making clients/consumers to break the normal norms of any business such that every business requires a digital orientation, meaning a digital focus in all business processes and functions 14,32].

However, Ezeokoli et al. [28], Kane et al. [33], Africa Practice [34] and Oladapo [35] observed that the construction and real estate sector, for example, ranks lowest in terms of digital maturity (i.e. Industry lags behind other industries in using ICT). So, to avoid being left out of the competition, construction industry needs to change its modus operandi in this digital era. This needs to happen rapidly [5], because most clients and consumers are getting more informed now and about $40 \%$ of the world population today are digitally compliance and those that cannot keep up with pace may be running the risk of being pushed out of business by competitors that are responding rapidly $[5,36]$.

In becoming a digital enterprise, construction industry will be required to thoroughly reimage the industry through a digital lens in terms of its processes and in customer engagement [15]. Also, it will have to develop a digital strategy with a defined scope and objectives on how to achieve the transformation. This is because the ultimate power of a digital strategy lies in its scope and objectives $[5,33]$. It is important to note therefore, that the evolving nature of technology makes transformation not a one-time investment and initiative; but the organisational, operational, and technological foundations is put in place to foster constant evolution and cross-functional collaboration [37]. To make this work, the strategy developed should be as such that it will win the hearts and minds of people at all levels in the organisation [31]. When, the industry is fully digitalised, it is believed to achieve direct or indirect better clients experience $[5,15,37]$. Other benefits of digital transformation as opined by previous researchers are shown in table 1 . 
Table 1. Benefits of Digital Transformation

\begin{tabular}{|c|c|l|}
\hline S/NO & \multicolumn{1}{|c|}{ Source } & \multicolumn{1}{c|}{ Benefits } \\
\hline 1 & BUSSINESSEUROPE [38] & $\begin{array}{l}\text { Shorten time-to-market, } \\
\text { Increase flexibility and product customisation at cost of economies of scale } \\
\text { Leads to greater customer choice and satisfaction, } \\
\text { Better commercial results of both existing and new products. }\end{array}$ \\
\hline 2 & Gartner [9] & $\begin{array}{l}\text { Help to achieve competitive advantage and differentiation using information and } \\
\text { technology }\end{array}$ \\
\hline \multirow{3}{*}{3} & Solis et al. [14] & $\begin{array}{l}\text { Updated company vision } \\
\text { Thriving culture of innovation } \\
\text { Improved customer journey } \\
\text { Greater competitive advantage } \\
\text { Increased internal collaboration } \\
\text { More empowered workforce } \\
\text { Improved efficiency } \\
\text { Deeper data analysis } \\
\text { Increased customer conversion and loyalty }\end{array}$ \\
& & \\
\hline
\end{tabular}

\subsection{Drivers and Threats to Digital Transformation}

Digital channels are proving pivotal to how the entire organisation competes, innovates and enhances the customer experience [32]. Accordingly, proliferations of digital channels, platforms and devices have helped to accelerate the emergence of new digital world, and its impacts are impossible to ignore [13]. Therefore, these impacts will be discussed on these headings: Drivers and Threats.

\subsubsection{Drivers}

Several studies [8,12,31,37,39] have articulated key drivers of digital transformation for any business to include:

- Profitability and new revenue growth,

- Customer satisfaction (because, customers' digital expectations are higher than ever before),

- Increase operational efficiency, convenience and the same high- quality technical standard,

- Increase business agility (i.e. speed of reaction to changes in the market),

- Increase employee productivity,

- Gain competitive advantage in order to stay relevant in a crowded and ever-changing market place, and

- $\quad$ Reduce the burden of data storage and management in a company.

\subsubsection{Threats}

Improving the digital customer experience takes collaboration, resources, leadership, and an understanding of its business value [14]. In going digital therefore, Solis et al. and Capgemini Consulting acknowledged that firms need to address the multiple challenges along this journey in order to create a seamless digital experience that meets consumer expectations along every touch point [14,31]. The most significant of these include aligning and managing the right resources and teams to focus on digital services, adopting 'digital-first' mind-set, building digital enthusiasm and willingness among middle management and operational levels; limited availability of the right digital skills and capabilities, uniting all our digital initiatives under one umbrella and then build on this consolidated portfolio, searching for the right alliance partner, shortage of suitably trained professionals, such as data scientists, refine digital services based on evolving needs, managing change lack of strategy and competing priorities $[12,15,31-33,40]$.

Having seen the indispensability of digital technologies in today's construction business and the possible driver and threats to the adaptability of the digital technologies in the global construction, this study is of the view that Nigeria construction industry is also influence by these technological waves. Thus there is need to assess the extent of these changes and the perception of construction professionals towards digital technologies in the industry. The result of this study will guide the industry's practitioners towards repositioning their business strategies for better competitiveness and posterity.

\section{Methodology}

This study was a survey research and was conducted in Anambra State, Nigeria. Although Anambra State is just one out of the thirty six states in Nigeria, statistically, this might not be a true reflection of the entire Nigeria. However, in terms of technology, there is no barrier or limit of penetration in any part of the country. So whatever affects one part also transcends to other part of the country. Based on this, the result of this study can be generalised to reflect the views of other construction professionals in Nigeria. Therefore the population of this study constitutes professionals in the construction industry particularly; Architects, Builders, Structural Engineers and Quantity Surveyor who are residing and practicing in Anambra state. The population of these professionals were obtained from the records available at various secretariats of the professional associations in the state. Subsequently, questionnaire administered to the selected construction professionals from where data on the extent of digital transformation in the Nigeria construction industry, the perception of construction professional about digital technologies, drivers and threats to digital 
transformation in Nigeria construction industry were collected. The respondents were asked to respond to each question based on five point Likert scale where $1=$ strongly disagree/ not at all and $5=$ strongly agree/critical. Table 2 showed the composition of the respondents with their respective population sizes and sample sizes. Thus, a total of 84 questionnaires were administered to the respondents and only 80 questionnaires were completed, returned and found useful. This represented a response rate of $95.23 \%$. Being a descriptive research, tables and charts were used in presenting the data presentation, while Mean Score Index (MSI) and Relative Important Index (RII) were computed used for ranking of factors posing as drivers and threats to digital transformation in the industry.

The Mean Score Index (MSI) is given as:

$$
M S I=\frac{\sum f_{i} x_{i}}{\sum f_{i}}
$$

And the Relative Important Index (RII) is computed as:

$$
R I I=\frac{\sum f_{i} x_{i}}{\mathrm{~A} \times \mathrm{N}}
$$

Where: $\sum=$ Sum;

$x_{\mathrm{i}}=$ Weight given to each statement by respondents and $i$ ranges $1-5$;

$f_{i}=$ Frequency of the response;

$\mathrm{A}=$ Highest Response Integer (i.e. 5); and

$\mathrm{N}=$ Total Number of Respondents.

Meanwhile Taro Yamani method of calculating sample size was employed to determine the appropriate sample size for this study [41]. Taro's formula is represented as:

$$
n=\frac{N}{1+\mathrm{N}(e)^{2}}
$$

Where: $n=$ the sample size; $\mathrm{N}=$ the population (105); and $e=$ the error margin (i.e. $5 \%$ ).

Thus, the sample size is given as: $n=\frac{105}{1+105(0.05)^{2}}$

$$
\begin{aligned}
& =\frac{105}{1.2625} \\
& =83.2
\end{aligned}
$$

Thus, sample size $(n)=84$

Table 2. Population Distribution

\begin{tabular}{|c|c|c|c|}
\hline S/NO & Professionals & Population Size & Sample size \\
\hline 1 & Architects & 15 & 12 \\
\hline 2 & Builders & 34 & 27 \\
\hline 3 & Quantity Surveyors & 25 & 20 \\
\hline 4 & Structural Engineers & 32 & 25 \\
\hline & Total & $\mathbf{1 0 5}$ & $\mathbf{8 4}$ \\
\hline
\end{tabular}

Source: Field survey (2015)

\section{Results}

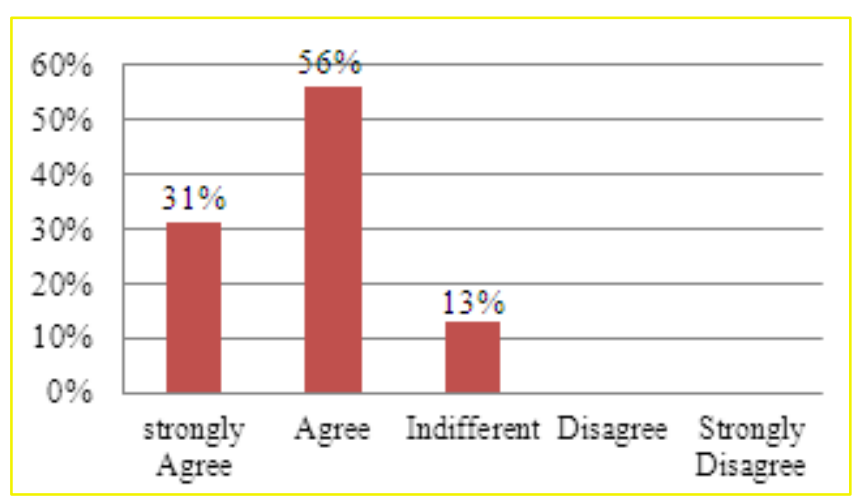

Figure 1. Perception on how digital technologies disrupting construction business activities

Figure 1 revealed that $87 \%$ of the respondents believed that digital technologies are seriously changing construction business activities with $13 \%$ showing indifferent. It also revealed that none of respondent indicated that digital technologies are not changing construction business activities. This implied that construction business activities in Nigeria are gradually transforming and responding to changes due to the emergence of new technology otherwise known as digital technology. However, the respondents mentioned that though the industry is responding to this wave of change, a lot of challenges are still facing the industry on its way towards full digital transformation.

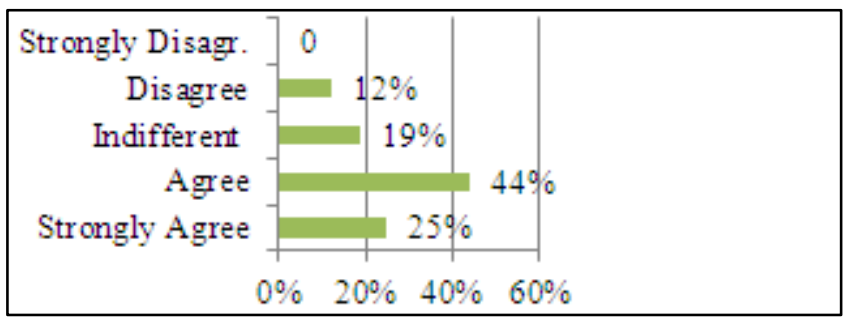

Figure 2. Digital transformation as an opportunity

Figure 2 revealed that $69 \%$ of the respondents saw digital technology as an opportunity, whereas about $31 \%$ of the respondents did not. Based on this, greater percentage of the construction professionals in the study area believed that digital transformation would open more opportunity for them but acknowledged that a lot of work has to be done to sensitise their members and management of construction firms on how going digital would benefit them more. When further asked why it was so, greater percentage cited numerous advantages attached with construction firm transforming digitally.

Figure 3 revealed that about $12 \%$ of the respondents viewed digital transformation as a threat, while $12 \%$ showed no concern. $75 \%$ of the respondents disagreed that digital transformation is a threat. Generally, they believed that digital transformation is more of opportunity than a threat, but a threat to those firms who are slow in adopting the new trend. Based on this, it can be deduced that digital transformation is more of opportunity than a threat due to its many advantages. 


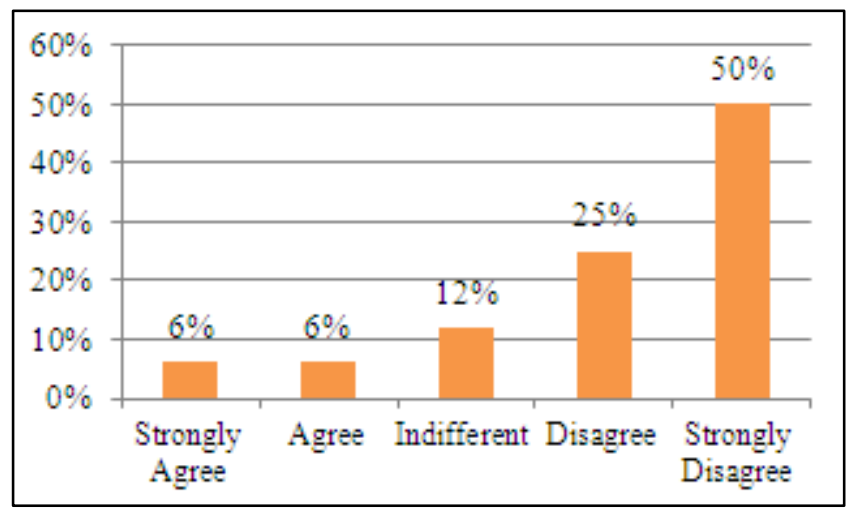

Figure 3. Digital transformation as a threat

Table 3. Drivers for digital transformation

\begin{tabular}{|c|c|c|c|c|c|c|c|c|c|c|}
\hline \multirow{2}{*}{ Drivers } & \multicolumn{5}{|c|}{ Frequency of Occurrence } & \multirow{2}{*}{$\left(\sum F\right)$} & \multirow{2}{*}{$\sum \mathrm{Fx}$} & \multirow{2}{*}{ Mean } & \multirow{2}{*}{ RII } & \multirow{2}{*}{ Rank } \\
\hline & 5 & 4 & 3 & 2 & 1 & & & & & \\
\hline $\begin{array}{l}\text { Generation of new revenue, revenue growth and } \\
\text { profitability }\end{array}$ & 24 & 36 & 8 & 12 & 0 & 80 & 312 & 3.90 & 0.78 & $7^{\text {th }}$ \\
\hline Customer satisfaction & 28 & 36 & 12 & 3 & 1 & 80 & 327 & 4.09 & 0.82 & $5^{\text {th }}$ \\
\hline $\begin{array}{l}\text { Increase in operational efficiency, convenience and } \\
\text { achieve high- quality technical standard }\end{array}$ & 35 & 25 & 11 & 9 & 0 & 80 & 326 & 4.08 & 0.82 & $6^{\text {th }}$ \\
\hline Increase business agility & 43 & 17 & 11 & 8 & 1 & 80 & 333 & 4.16 & 0.83 & $4^{\text {th }}$ \\
\hline Increase employee productivity & 44 & 24 & 12 & 0 & 0 & 80 & 352 & 4.40 & 0.88 & $2^{\text {nd }}$ \\
\hline $\begin{array}{l}\text { Gain competitive advantage in order to stay relevant in a } \\
\text { crowded and ever-changing market place }\end{array}$ & 28 & 44 & 8 & 0 & 0 & 80 & 340 & 4.25 & 0.85 & $3^{\text {rd }}$ \\
\hline Reduce the burden of data storage and management & 43 & 37 & 0 & 0 & 0 & 80 & 363 & 4.54 & 0.91 & $1^{\text {st }}$ \\
\hline
\end{tabular}

The response in table 3 revealed that the key drivers of digital transformation in the construction industry are: reduction of the burden of data storage and management $(0.91)$, increase employee productivity $(0.88)$ and gain competitive advantage $(0.85)$. However, table 3 also revealed that generation of new revenue, revenue growth and profitability $(0.78)$ and increase in operational efficiency, convenience and achieve high- quality technical standard (0.82) are one of the motivator to digital transformation but are not prime in the study area. Although there are many factors that can affect the adoptability of digital technologies in the construction industry operations, table 3 revealed that the most critical among them are reduction in the burden of data storage and management, increase in employee productivity and gaining competitive advantage over other firms.

Table 4. Threats to digital transformation

\begin{tabular}{|c|c|c|c|c|c|c|c|c|c|c|}
\hline \multirow{2}{*}{ Threats } & \multicolumn{5}{|c|}{ Frequency of Occurrence } & \multirow{2}{*}{$\left(\sum \mathrm{F}\right)$} & \multirow{2}{*}{$\sum F x$} & \multirow{2}{*}{ Mean } & \multirow{2}{*}{ RII } & \multirow{2}{*}{ Rank } \\
\hline & 5 & 4 & 3 & 2 & 1 & & & & & \\
\hline $\begin{array}{l}\text { Aligning and managing resources and teams to } \\
\text { focus on digital services }\end{array}$ & 16 & 40 & 16 & 8 & 0 & 80 & 304 & 3.80 & 0.76 & 5 th \\
\hline Adopting digital mind-set, & 20 & 33 & 17 & 4 & 6 & 80 & 297 & 3.71 & 0.74 & 7th \\
\hline $\begin{array}{l}\text { Building digital enthusiasm and willingness among } \\
\text { management. }\end{array}$ & 25 & 36 & 7 & 4 & 8 & 80 & 306 & 3.83 & 0.77 & $3 \mathrm{rd}$ \\
\hline $\begin{array}{l}\text { Limited availability of the right digital skills and } \\
\text { capabilities, }\end{array}$ & 30 & 30 & 8 & 4 & 8 & 80 & 342 & 4.28 & 0.86 & 2nd \\
\hline Lack of collaborative and sharing culture & 20 & 23 & 17 & 16 & 4 & 80 & 279 & 3.49 & 0.70 & 10th \\
\hline Searching for the right alliance partner, & 23 & 13 & 24 & 15 & 5 & 80 & 298 & 3.73 & 0.75 & 6th \\
\hline Shortage of suitably trained professionals & 45 & 23 & 9 & 3 & 0 & 80 & 350 & 4.38 & 0.88 & $1 \mathrm{st}$ \\
\hline Security concerns & 16 & 31 & 21 & 12 & 0 & 80 & 291 & 3.64 & 0.73 & 8 th \\
\hline Managing change & 12 & 24 & 36 & 4 & 4 & 80 & 264 & 3.30 & 0.66 & 13th \\
\hline Culture/structure of organisation & 13 & 23 & 27 & 11 & 6 & 80 & 266 & 3.33 & 0.67 & 12 th \\
\hline Lack of strategy and competing priorities & 12 & 36 & 20 & 10 & 2 & 80 & 286 & 3.58 & 0.72 & 9th \\
\hline Lack of critical knowledge & 26 & 22 & 24 & 8 & 0 & 80 & 306 & 3.83 & 0.77 & $3 \mathrm{rd}$ \\
\hline Technology challenges & 16 & 16 & 16 & 25 & 7 & 80 & 249 & 3.11 & 0.63 & 16 th \\
\hline Lack of fund & 20 & 20 & 16 & 17 & 7 & 80 & 269 & 3.36 & 0.67 & 12 th \\
\hline Lack of employee incentives & 4 & 28 & 28 & 20 & 0 & 80 & 276 & 3.45 & 0.69 & 11 th \\
\hline Lack of organisational agility & 9 & 15 & 24 & 24 & 8 & 80 & 233 & 2.91 & 0.58 & 17 th \\
\hline $\begin{array}{l}\text { Lack of entrepreneurial spirit, willingness to take } \\
\text { risks }\end{array}$ & 24 & 20 & 4 & 20 & 12 & 80 & 264 & 3.30 & 0.66 & 13th \\
\hline
\end{tabular}


Table 4 revealed that the critical factors militating against digital transformation in the Nigeria construction industry are: shortage of suitably trained professionals $(0.88)$, limited availability of the right digital skills and capabilities (0.86), lack of critical knowledge (0.77), building digital enthusiasm and willingness among management (0.77), aligning and managing resources and teams to focus on digital services (0.76) and searching for the right alliance partner (0.75). It further revealed that although lack of organisational agility (0.58), technology challenges (0.63), lack of entrepreneurial spirit, willingness to take risks (0.66) and managing change (0.66) pose some challenges to adopting digital technologies in the Nigeria construction industry, they are not critical challenges toward digital transformation in the in the industry but should be taken note of .

\section{Discussion}

The result of this study showed that the Nigerian construction industry is still saddled with paper based practices and processes. Although greater percentage of respondents agreed that construction business activities in Nigeria are gradually transforming due to emergence of new technology, greater percentage also viewed digital transformation of the industry more as an opportunity than a threat. However, it was observed that the construction industry is still at infancy level in terms of transforming digitally due to lack capacity, critical knowledge and digital transformation enthusiasm among managerial teams.

Meanwhile, the study revealed that the most observed drivers of digital transformation in the Nigeria construction industry were the desire to reduce burden of data storage and management, increase in employee productivity and gaining competitive advantage and remaining relevant in the construction market. This result is in line with that of the International Data Group [12] and Bossink [30] which found that about 83 percent of the surveyed executives cited greater operational efficiency, followed by enhanced business agility, higher employee productivity and stronger competitive advantage as the most important drivers of their transformation efforts, and the results of $[8,30,31,37,39]$.

Likewise, it was found that the most critical threats to digital transformation in the Nigeria construction industry were shortage of suitably trained professionals, limited availability of the right digital skills and capabilities, building digital enthusiasm and willingness among management, and lack of critical knowledge. This is also in line with [12,15,31-33,39] findings. More importantly, the study aligned with the diffusion of innovation theory in the construction industry to understand the elements of the adoption process of new practices for better adaptability of digital transformation.
Digital technologies are gradually disrupting and transforming business practices and procedures globally and Nigerian construction is not immune from this disruptive and transformative effect, because digital transformation is now a reality. Accordingly, the study has identified various drivers and threats of digital transformation in the Nigeria construction industry. Interestingly, the study found that digital transformation was perceived as more of opportunity than a threat. Construction professionals believed that firms and organisations that have been digitally transformed have competitive edge over others. It was also found that, most construction firms were gradually gearing towards undergoing formal digital transformation while others were still getting ready to take-off. However, it was found that the application of digital technologies skills and its transformation in Nigerian construction industry was still at infantry level. This is due to lack capacity at all levels, lack of critical knowledge, lack of digital transformation enthusiasm among construction stakeholders and difficulty in finding the right partner in this quest. Despite this, it was evident that digital transformation would help construction organisations to bettering their data storage capacity and management, increasing employee productivity and gaining competitive advantage over others both now and in future.

On this footing, this study has made some theoretical, methodological, and practical contributions in the existing body of knowledge. It has highlighted the importance of construction firms going digital so as to measure up with the prevailing global waves of change. It has opened the windows of opportunities for any serious construction organisation that wants to remain competitive in the construction business. Since construction industry generally is believed to be lagging in adopting innovative changes, which has equally been reflected in the innovation research in the industry, this study has contributed greatly in this regard especially with respect to the Nigerian construction industry.

Consequently, the study recommended government collaboration with relevant professional bodies in the construction industry towards working out appropriate roadmap that would position the industry in the right track of digital transformation. Government needs to equally support this transformation waves through regulations and policies, and procurement systems. Furthermore, the construction firms should be encouraged forming alliance with other firms either within or outside the industry that has attained formal digital transformation in order to help overcome the skill related problems. Finally, adequate capacity building, collaboration, knowledge sharing and transfer among construction stakeholders are very necessary in this quest.

\section{REFERENCES}

[1] A. Ganguly. Optimisation of IT and Digital Transformation: Strategic Imperative for creating a New Value Delivery 
Mechanism and a Sustainable Future in Organisation!, European Journal of Business and Innovation Research, Vol. 3, No. 2, pp. 1-13, 2015.

[2] P. Hoberg. H. Krcmar, G. Oswald, B. Welz. Skills for Digital Transformation: Technical University of Munich, Chair for Information Systems Boltzmannstr, Garching, 2015. Online available from http://www.winfobase.de/.

[3] C. I. Onyia. Evaluation of E-working Environment within the Nigerian Construction Industry, Challenges and Prospects (A case study of Abuja Nigeria), Unpublished MSc Thesis, Nnamdi Azikiwe University, Awka, Nigeria, 2014.

[4] J. Gole, R. Kaltenbrunner. How Digital Transformation is Changing Business in CEE, International Data Corporation (IDC), 2014. Online available from www.idc.com.

[5] Q. Corver, G. Elkhuizen. A Framework for Digital Business Transformation, Cognizant, 2014. Online available from http://www.cognizant.com.

[6] Mckinsey \& Company. Perspective on Digital Business, Mckinsey Centre for Business Technology, 2012. Online available from www.mckinsey.com.

[7] S. O. Olukayode, A. A. Adeyemi. A survey of the State of the Art of E- Tendering in Nigeria, Journal of Information Technology in Construction (ITcon), Vol. 16, pp. 557-576, 2011. Online available from http://www.itcon.org/2011/32.

[8] M. Bahl. Asia Rising: Digital Driving, Cognizant Centre for the Future of Work, 2015. Online available from http://www.futureofwork.com.

[9] Gartner. Building the Digital Platform: Insights from the 2016, Gartner CIO Agenda Report, 2015. Online available from http://gartner.com/cioagenda.

[10] B. Bloching, P. Leutiger, T. Oltmanns, C. Rossbach, T. Schlick, R. Gerrit, Q. Paul, O. Shafranyuk. The Digital Transformation of Industry, München, Germany, Roland Berger Strategy Consultants Gmbh \& Bundesverband Der Deutschen Industrie E.V. (BDI), 2015. Online available from www.rolandberger.com/www.think-act.com/www.bdi.eu.

[11] D. Phillip, N. Thompson. Built Environment 2050, A Report on Our Digital Future, Construction Industry Council, 2014.

[12] International Data Group (IDG). Digital Transformation: Crossing the Chasm from IT to the Business. Market Pulse, White Paper, 2012. Online available from http://www.dell.com/learn/us/en/04/campaigns/delldoesdigit $\mathrm{al} ? \mathrm{c}=\mathrm{us} \& \mathrm{l}=\mathrm{en} \& \mathrm{~s}=\mathrm{bsd}$.

[13] Ernest \& Young (EY). Risk and Opportunity in an Increasingly Digital World, Insurance Governance Leadership Network, Tapestry Networks Inc, 2015. Online available from www.tapestrynetworks.com.

[14] B. Solis, C. Li, J. Szymanski. Digital Transformation: Why and How Companies are Investing in New Business Model to Lead Digital Customer Experience, Altimeter Group, 2014. Online available from http://www.altimetergroup.com/ disclosure.

[15] EMC. Competing for Digital Customers: Why Companies Must Embrace Digital Transformation Now, EMC Corporation, 2016. www.emc.com.

[16] E. B. Paz, P. Viriyavadhana. Facility Management, AU
Journal of Technology, Vol. 6, No.1, pp. 1-5, 1995.

[17] World Economic Forum. Shaping the Future of Construction: A Breakthrough in Mindset and Technology, Industry Agenda prepared in collaboration with The Boston Consulting Group, de Almeida P. R, Bühler M., Gerbert P. Castagnino S. Rothballer C. (Eds). Geneva, World Economic Forum, 2016. Online available from www.weforum.org.

[18] J. Dale. Innovation in Construction: Ideas are the currency of the future, CIOB Survey, 2007. www.ciob.org.uk

[19] M. Abubakar, Y. M. Ibrahim, D. Kado, K. Bala. Contractors Perception of the Factors Affecting Building Information Modelling (BIM) Adoption in the Nigerian Construction Industry, Computing in Civil and Building Engineering, pp. 167-178, 2014.

[20] I. Mbamali, A. J. Okotie. An Assessment of the Threats and Opportunities of Globalisation on Building Practice in Nigeria, American International Journal of Contemporary Research, Vol. 2, No. 4, pp. 143-150, 2012.

[21] J. Egan. Rethinking construction: The Report of the Construction Task Force on the Scope for Improving the Quality and Efficiency of the UK Construction Industry, 1998. Online available from http://www.constructingexcellence.or g.uk.

[22] D. G. Proverbs, G. D. Holt, H .Y. Cheok. Construction Industry Problems: The Views of UK construction Directors. In: Akintoye, A. (Ed.), 16th Annual ARCOM Conference, Glasgow Caledonian University. Association of Researchers in Construction Management, Vol. 1, pp. 73-81, 6-8 September, 2000.

[23] C. Tatum. Organising to Increase Innovation in Construction Firms, Journal of Construction Engineering and Management, December 1989, Vol. 115, No. 4, pp. 602-617, 1989. Doi: 10.1061/(ASCE)0733-9364(1989)115:4(602).

[24] A. M. Blayse and K. Manley. Key influences on construction innovation. Construction Innovation, Vol. 4, pp. 143-154, 2004.

[25] S. Asad, P. Fuller, W. Pan, A. R. J.Dainty. Learning to innovate in construction: a case study. In: Khosrowshahi, F (Ed.), 21 st Annual ARCOM Conference, 7-9 September 2005, SOAS, University of London. Association of Researchers in Construction Management, Vol. 2, pp. 1215-1224, 2005.

[26] R. B. Isa, R. A. Jimoh, E. Achuenu. An Overview of The Contribution of Construction Sector to Sustainable Development in Nigeria, Net Journal of Business Management, Vol. 1, No. 1, pp. 1-6, 2013.

[27] F. O. Ezeokoli, S. C. Ugochukwu, N. N. Agu, S. C. Akabougu. An Assessment of the Use, Benefits and Challenges of the 'Cash-Lite' Policy, For Construction Projects in Anambra State, Nigeria; European Scientific Journal, Vol. 12, 16,pp. 313-328, 2016.

[28] F. O. Ezeokoli, S. C. Ugochukwu, K. C. Okolie. Actualisation of a Cashless Construction Industry in Nigeria: Perceptions of Stakeholders in Anambra State, International Journal of Multidisciplinary Research and Development, Vol. 3, No. 1, pp. 246-253, 2016.

[29] National Bureau of Statistics (NBS). Nigerian Gross Domestic Product Report, First Quarter 2016, Issue 9, 2016. Online available from www.nigeranstat.gov.ng. 
[30] B. A, G. Bossink. Managing Drivers of Innovation in Construction Networks. Journal of Construction Engineering and Management, Vol. 130, No. 3, 337-345, 2004.

[31] Capgemini Consulting. Accelerating Digital Transformation, Digital Transformation Review, 2013.

[32] B. Shah, G. Hartman, B. Whimmple. CMOs: Time for Digital Transformation or Risk Being Left on the Sidelines, 2014. Online available from www.accenture.com.

[33] G. C. Kane, D. Palmer, A. N. Phillips, D. Kiron, N. Buckley. Strategy, not Technology, Drives Digital Transformation Becoming a Digitally Mature Enterprise, MIT Sloan Management Review articles, 2015. Online available from http://www.sloanreview.mit.edu.

[34] Africa Practice. The Social Media Landscape in Nigeria: The ho, the What and the How, 2014. Online available from http:// www.africapractice.com.

[35] A. A. Oladapo. An investigation into the use of ICT in the Nigerian construction industry, ITcon Journal, Vol. 12, pp. 261-277, 2007

[36] M. Blondel, M. Zintel, H. Suzuki. Airports 4.0: Impact of
Digital Transformation on Airport Economics Viewpoint, Arthur D. Little, 2015. Online available from www.adlittle.com.

[37] Forrester. Digital Transformation in the Age of the Customer, Accenture Interactive, 2015. Online available from www.forrester.com

[38] Business Europe. BUSINESSEUROPE Recommendations for a Successful Digital Transformation in Europe, 2015. Online available from www.businesseurope.eu.

[39] P. Dunne. The Digital Capability and Skills Dilemma, Digital Skills Academy Presentation to IVI Summit, 9th September, 2014.

[40] L. Alvarez, B. El-Darwiche, S. Dutta, A. Behar, A. Enriquez, A. D. Battista, J. Garrity, M. Hagstroem, T. Geiger M. Herzog, L. Hosman, F.C. Grijpink, J. Jung. The Global Information Technology Report 2015: ICTs for Inclusive Growth, World Economic Forum, 2015. Online available from www.weforum.org/gitr.

[41] T. Yamane. Statistics, An Introductory Analysis, 2nd Edition. New York: Harper and Row, 1967. 